\section{DISCLAIMER}

This report was prepared as an account of work sponsored by an agency of the United States Government. Neither the United States Government nor any agency thereof, nor any of their employees, makes any warranty, express or implied, or assumes any legal liability or responsibility for the accuracy, completeness, or usefulness of any information, apparatus, product, or process disclosed, or represents that its use would not infringe privately owned rights. Reference herein to any specific commercial product, process, or service by trade name, trademark, manufacturer, or otherwise does not necessarily constitute or imply its endorsement, recommendation, or favoring by the United States Government or any agency thereof. The views and opinions of authors expressed herein do not necessarily state or reflect those of the United States Government or any agency thereof.
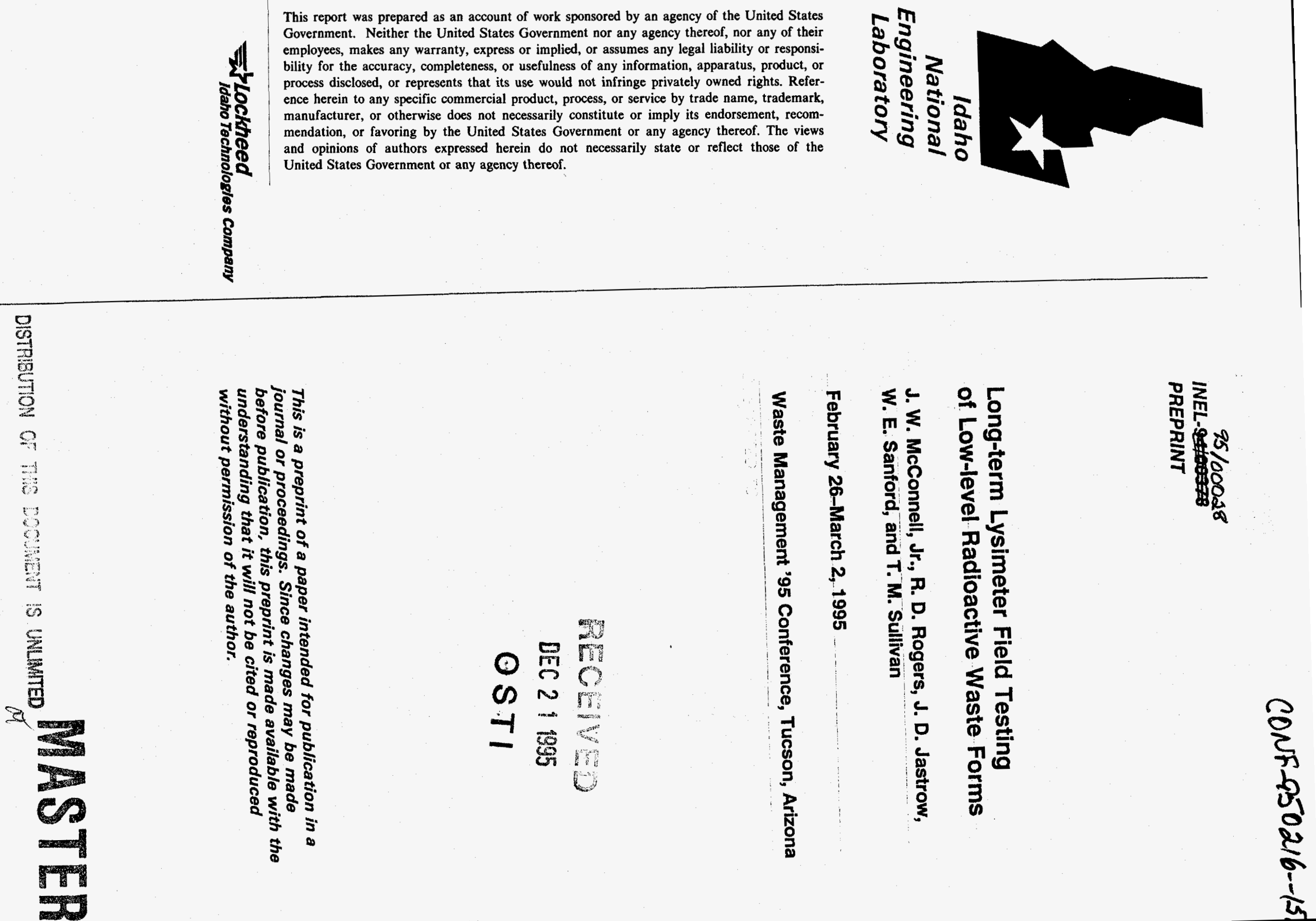


\section{DISCLAMIER}

Portions of this document may be illegible in electronic image products. Images are produced from the best available original document. 


\title{
Long-term Lysimeter Field Testing of Low-level Radioactive Waste Forms
}

\author{
John W. McConnell, Jr., Robert D. Rogers, Julie D. Jastrow, ${ }^{a}$ \\ William E. Sanford, and Terry M. Sullivan ${ }^{\mathrm{c}}$ \\ Idaho National Engineering Laboratory \\ P.O. Box 1625, Idaho Falls, Idaho 83415
}

\begin{abstract}
The Field Lysimeter Investigations: Low-Level Waste Data Base Development Program is obtaining information on the performance of radioactive waste forms. Ion-exchange resins from a nuclear power station were solidified into waste forms using Portland cement and vinyl esterstyrene. These waste forms are being tested to obtain information on survivability of waste forms in a disposal environment and to develop a low-level waste data base. Radionuclide releases from those waste forms during the first 9 years of sampling have been evaluated. Also, upward migration of radionuclides was recently discovered. Lastly, lysimeter data are applied to a performance assessment source term model.
\end{abstract}

\section{INTRODUCTION}

The purpose of this paper is to present the experimental results of the two instrumented lysimeter arrays over 9 years of operation and to compare these soil leaching results to bench leaching results from similar waste forms and to predictions of the Disposal Unit Source Term (DUST) code. While results of this program have been presented at previous WM meetings, this paper gives an update of the study, which includes further discussion of the upward migration of cesium-137 and cesium-134 in one unit of the Oak Ridge National Laboratory array. Results of analysis of sand cores from that lysimeter are presented and discussed. Also, cumulative radionuclide release from the waste forms to the leachate water passing through the soil columns is presented and compared to bench leach test cumulative fractional releases from similar waste forms.

Concern over the practices associated with the disposal of low-level radioactive waste has resulted in a very real need to obtain accurate data on the long-term field performance of these wastes. The U.S. Nuclear Regulatory Commission (NRC) has enacted regulations that link low-level radioactive waste acceptance criteria to the long-term satisfactory performance of the disposal facility. Under Code of Federal Regulations (CFR) 10, Part 61, "Licensing Requirements

a. Argonne National Laboratory, Argonne, IL 60439.

b. Oak Ridge National Laboratory, Oak Ridge, TN 37831.

c. Brookhaven National Laboratory, Upton, NY 11973. 
for Land Disposal of Radioactive Wastes" (1), commercially generated low-level radioactive waste is classified as Class A, B, or C. Wastes classified as either Class B or Class C must be stabilized for a minimum of 300 years.

To verify the 300 -year stability of waste forms, the NRC specifies the use of short-term standardized tests with the intention that such tests would provide information relevant to nearsurface disposal performance objectives. Those tests, which were initially published in the NRC Branch "Technical Position on Waste Form" (2), and have been revised in Revision 1 of the Technical Position (3), continue to undergo critical reviews to determine their applicability to the 300 -year stability requirements.

A central requirement for disposing low-level radioactive waste is the need for a detailed understanding of the waste form behavior. That is necessary because the radionuclide source is the driving force behind the site performance. A major requirement in any site licensing is the site performance assessment, which is used to evaluate whether or not a proposed disposal site will meet performance objectives. Assumptions regarding the performance of the buried waste form have a direct bearing on the outcome of the performance assessment.

The objective of the Field Lysimeter Investigations: Low-Level Waste Data Base Development Program is to compare the results of short-term laboratory leach testing, performed earlier by the INEL, with actual leaching in the field. Also, the waste forms are being field-tested to develop a low-level radioactive waste leach rate data base. This program, funded by the NRC, has been operating lysimeters for over 9 years to obtain information on the performance of radioactive waste forms in a disposal environment and to investigate waste form stability per requirements of $10 \mathrm{CFR} 61$. The experiment measures the releases of radionuclides and chemical species from the waste forms and the subsequent transport through soil columns to sampling locations within the lysimeters. This study was developed to field test waste forms composed of solidified ion-exchange resin materials from EPICOR- $\Pi^{\mathrm{a}}$ prefilters used in the cleanup of Unit 2 of the Three Mile Island Nuclear Power Station (4). Wastes used in the study are significant because they have high loadings of radionuclides and are comprised on ion-exchange media of the type used by the nuclear industry.

\section{EXPERIMENT DESCRIPTION}

Wastes used in the experiment include a mixture of highly loaded, nuclear-grade, synthetic, organic ion-exchange resins from EPICOR-II prefilter PF-7 and a mixture of organic-exchange resins and an inorganic zeolite from prefilter PF-24. Solidification agents employed to produce the $4.8 \times 7.6-\mathrm{cm}$ cylindrical waste forms used in the study were Portland Type I-II cement and DOW vinyl ester-styrene (VES). Seven of the waste forms were stacked end-to-end and inserted into each lysimeter to provide a 1-L volume. The PF-7 waste contained $89 \%$ of the radionuclide activity as cesium-137, while PF-24 contained 94\% cesium-137. The PF-7 waste also contained $5 \%$ strontium-90, and PF-24 contained 1\% strontium-90. There were also measurable amounts of

a. References herein to any specific commercial product, process, or service by trade name, trademark, manufacturer, or otherwise, does not necessarily constitute or imply its endorsement, recommendations, or favoring by the United States Government or any agency thereof. 
cesium-134, cobalt-60, and antimony-125 found in those wastes. Details on waste-form descriptions, formulations, and technical position testing are given in References (4) and (5). A listing of lysimeter waste form and fill material types are given in Reference (6).

Ten lysimeters were used in this study: five at Oak Ridge National Laboratory (ORNL) in Tennessee and five at Argonne National Laboratory-East (ANL-E) in Illinois. The lysimeters were designed to be self-contained units that will be disposed at the termination of the study. Each lysimeter is a $0.91 \times 3.12-\mathrm{m}$ right-circular cylinder divided into an upper compartment that contains fill material, waste forms, and instrumentation, and a lower compartment for collecting leachate (Figure 1). Four lysimeters at each site are filled with soil; a fifth, used as a control, is filled with inert silica oxide sand. The lysimeters at ANL-E contain soil indigenous to the site, while the ORNL lysimeters contain soil taken from Savannah River Laboratory in South Carolina. The soil columns are $2.21 \mathrm{~m}$ deep.

Instrumentation in each lysimeter includes moisture cup soil-water samplers and soil moisture/ temperature probes. The probes are connected to an onsite data acquisition system (DAS), which also collects data from a field meteorological station located at each site. Porous cup soil-water samplers and the leachate collection compartment comprise the water sampling components of each lysimeter (Figure 1). Incoming precipitation moves downward through the soil column to the waste form, then on to cups 3 and 1, and finally to the leachate collector at the bottom. Moisture entering the soil at the edge of the lysimeter encounters cups 5, 4, or 2 as it moves downward. Samples of moisture are withdrawn from the cups and the collector. Radial movement of waste form releases are detected in cups 5, 4, and 2, while vertical release is observed by cups 3 and 1. Lysimeter design, installation, instrumentation, operation, and data acquisition are explained in Reference (6).

Monitoring of the lysimeters at ANL-E and ORNL began with the collection of liquid samples in September 1985 (3 months from the time of placement) and has continued with sample collection on approximately a quarterly basis thereafter. Samples of liquids were taken from locations near the waste forms and from the leachate collectors to track the migration of radionuclides, primarily cesium-137. The water samples were analyzed for strontium-90 and gamma-producing nuclides. Each month, data stored on a cassette tape in the DAS were retrieved and translated into an IBM PC-compatible disk file. Soil moisture and temperature at three elevations in each lysimeter, along with a complete weather history, were recorded on a continuing basis by the DAS. Testing results are presented in Reference (7) as well as in this paper.

\section{RESULTS AND DISCUSSION}

\section{Weather and Soil Data}

Precipitation, air temperature, wind speed, and relative humidity were recorded continuously by the ANL-E and ORNL DAS during the experiment. The cumulative volume of leachate from the lysimeters since the initiation of field work, and examples of the lysimeter soil temperature and moisture data obtained at ANL-E and ORNL can be found in Reference (7). Data recorded in FY-94 indicate that the lysimeter soil columns at both sites have remained moist during the last reporting period. 


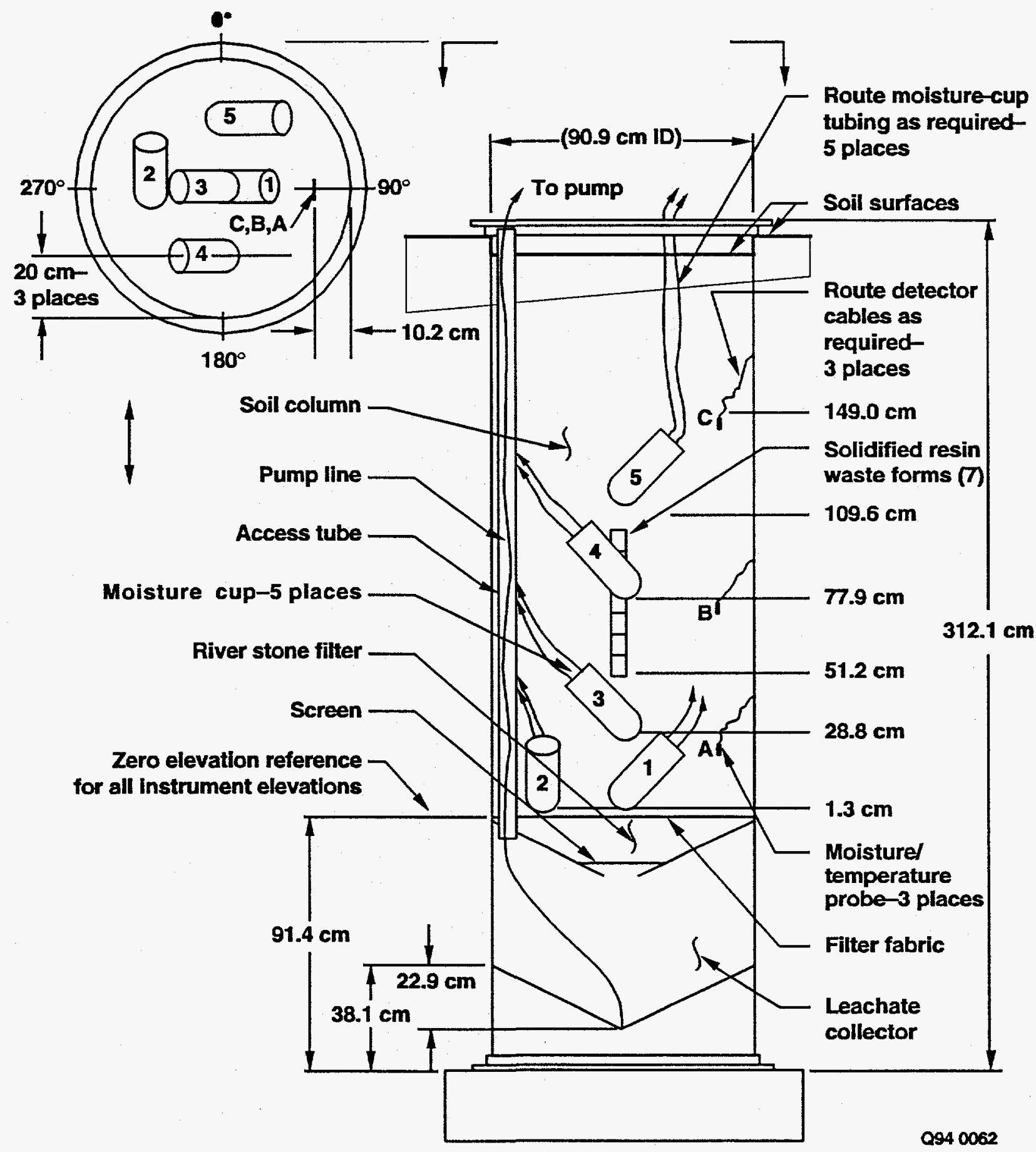

Figure 1. Lysimeter vessel component locations. The base of the soil column is the zero elevation reference. 


\section{Radionuclide Data}

Figures 2 and 3 show examples of data on the cumulative amounts of nuclides as determined in water samples obtained from ANL-E and ORNL leachate collectors, respectively. Other data show that not all nuclides consistently appeared in the water obtained from the moisture cups or the leachate collectors. The nuclide that appeared with the most regularity at both sites was strontium-90. Table I contains a comparison of the cumulative fractional release of strontium-90 and cesium-137 found in the moisture cups and leachate water. Consistent significant occurrences of strontium- 90 have been observed in all the number 3 cups $(22.4 \mathrm{~cm}$ below the waste form in the soil column) at both ANL-E and ORNL.

At both ORNL and ANL-E, recovery of strontium-90 in cups 3 and the leachate collectors indicates a varied waste form performance (Table I). Recovery of strontium-90 in the ORNL cups is comparable for those lysimeters containing the cement waste forms and one of the two containing VES waste forms. However, the cups at ANL-E are recovering much more strontium-90 from the VES waste forms compared to the cement waste forms. These data indicate that releases from the cement waste forms are generally larger than from VES waste forms.

Movement of the nuclide into the leachate collectors of the inert, sand-filled control lysimeter 5 is much greater than that of the other lysimeters and thus provides evidence of the moderating effect of soil (versus the inert sand) in those lysimeters. During the past several years, leachate collector water from the control lysimeters at each site has contained amounts of strontium-90 at least an order of magnitude larger than releases from the soil lysimeters (Figures 2 and 3) (7). The total strontium-90 being measured in the leachate collector waters remains somewhat inconsistent between the two sites (Table I). It is suspected that this represents a difference in how the environment at the two sites affects the movement of strontium- 90 being released from the waste forms. The higher release of strontium- 90 from the ORNL control lysimeter waste form reflects the nearly $50 \%$ higher rainfall experienced at that site over that seen at ANL-E.

Gamma-producing nuclides continue to occur with regularity at both sites (Table I). However, only waste forms at ORNL are releasing detectable amounts of cesium-137 to the leachate waters (Table I). It is not possible to make a comparison of cesium-137 releases from cement and VES waste forms at this time due to the small releases.

Table II is a comparison of cumulative fractional releases from field testing EPICOR-II waste forms in lysimeters to releases from bench-leach-testing similar waste forms as reported in Reference $(5,8)$. Releases observed in the lysimeter is at least four orders of magnitude less for strontium- 90 and at least five orders of magnitude less for cesium-137 in soil. It is interesting to note that release of strontium- 90 in the sand-filled lysimeter is only one or two orders of magnitude less than bench test results. At the present rate of increase (see Figures 2 and 3), these cumulative fractional releases will be of similar magnitude in a couple of years. 


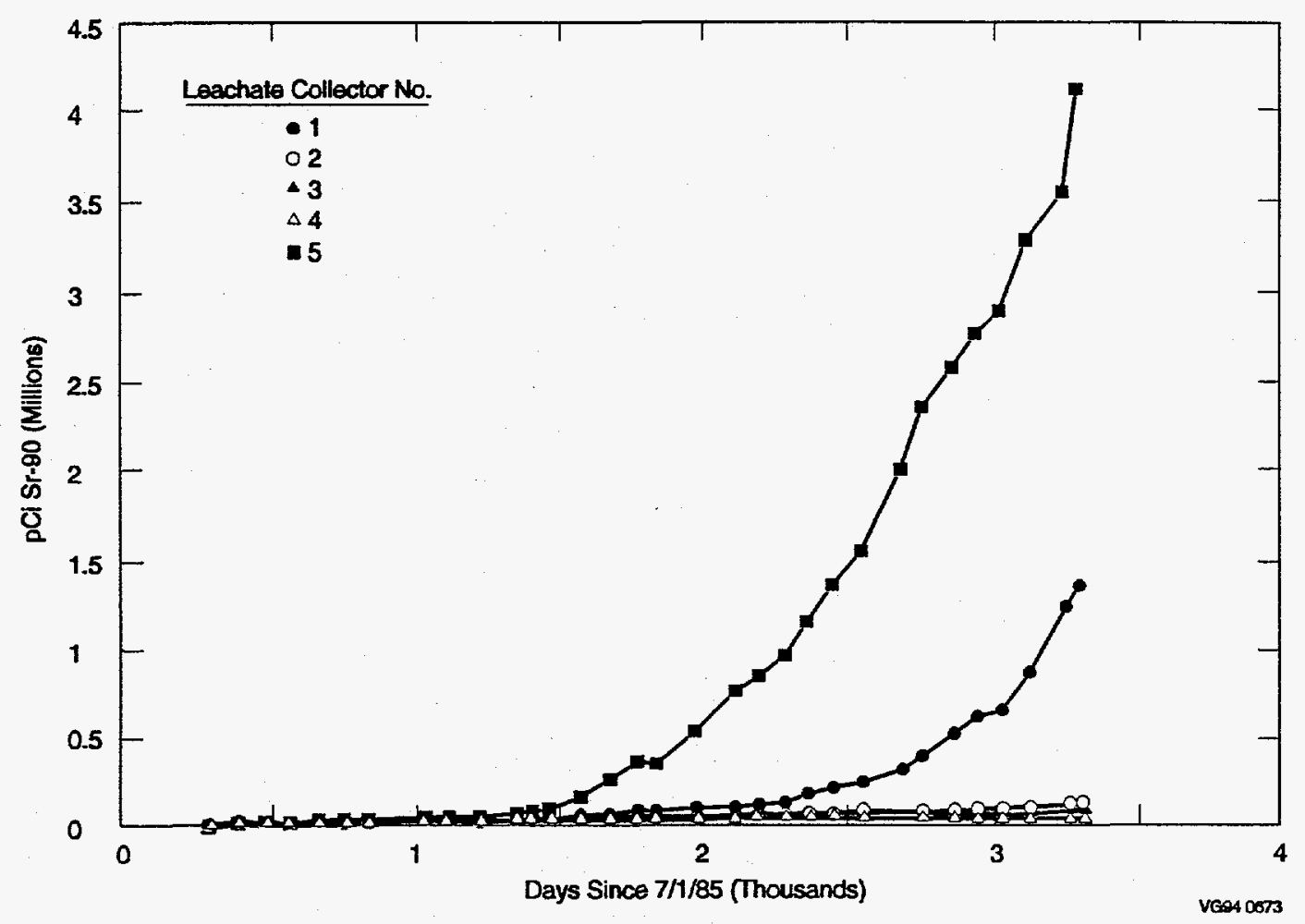

Figure 2. ANL-E cumulative strontium- 90 collected in lysimeter leachate collectors.

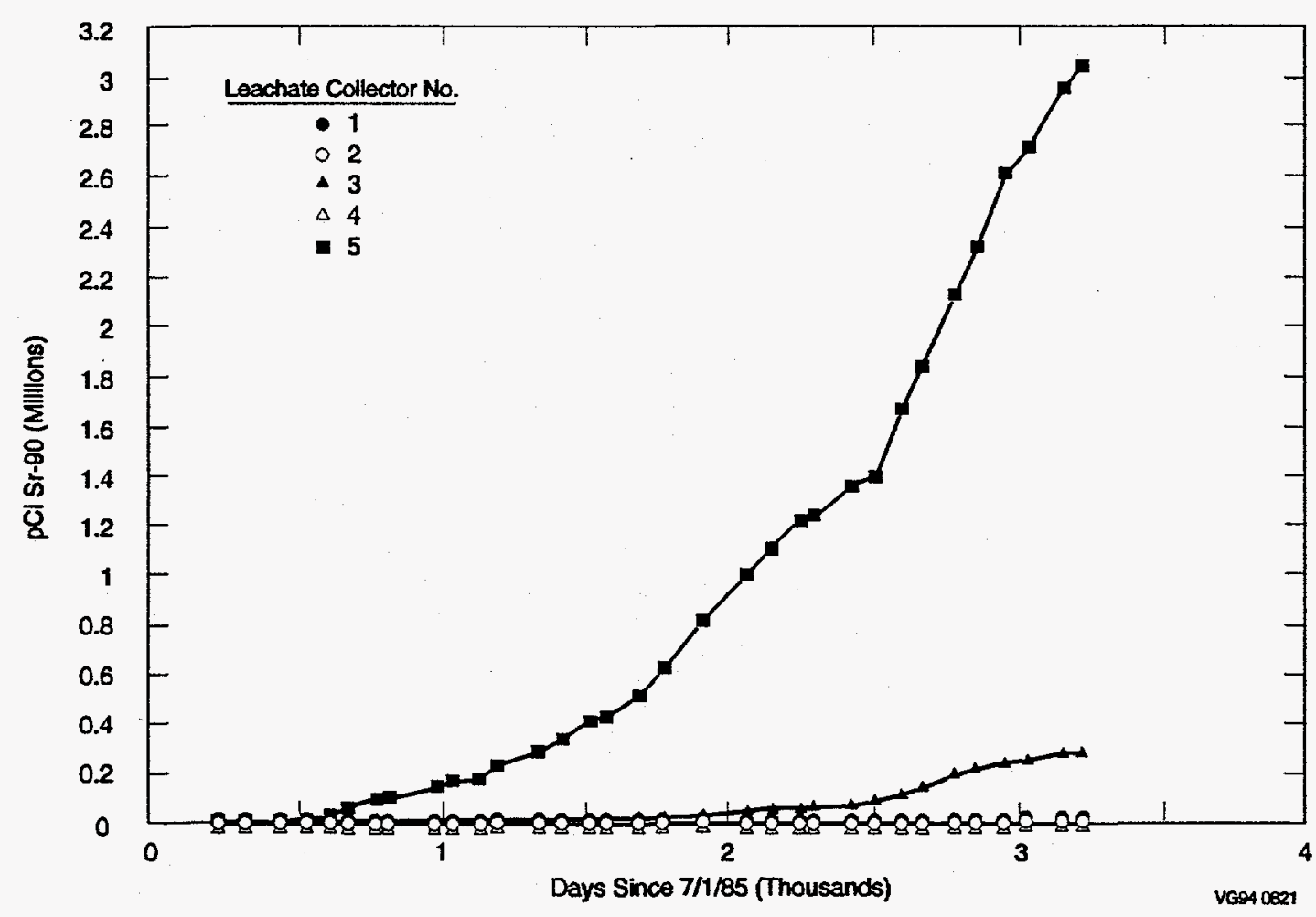

Figure 3. ORNL cumulative strontium-90 collected in lysimeter leachate collectors. 
Table 1. Cumulative fractional release of strontium-90 and cesium-137 per lysimeter in moisture cups and leachate water through July 1994.

\begin{tabular}{|c|c|c|c|c|c|c|c|c|c|}
\hline \multirow{3}{*}{$\begin{array}{l}\text { Lysimeter } \\
\text { number }\end{array}$} & \multirow{3}{*}{$\begin{array}{c}\text { Solidification } \\
\text { agent }\end{array}$} & \multicolumn{4}{|c|}{$\begin{array}{c}\text { Cumulative fractional release } \\
\text { of strontium- } 90\end{array}$} & \multicolumn{4}{|c|}{$\begin{array}{l}\text { Cumulative fractional release } \\
\text { of cesium- } 137\end{array}$} \\
\hline & & \multicolumn{2}{|c|}{$\begin{array}{c}\text { Moisture } \\
\text { cups }\end{array}$} & \multicolumn{2}{|c|}{$\begin{array}{l}\text { Leachate } \\
\text { collectors }\end{array}$} & \multicolumn{2}{|c|}{$\begin{array}{l}\text { Moisture } \\
\text { cups }\end{array}$} & \multicolumn{2}{|c|}{$\begin{array}{l}\text { Leachate } \\
\text { collectors }\end{array}$} \\
\hline & & ANL-E & ORNL & ANL-E & ORNL & ANL-E & ORNL & ANL-E & ORNL \\
\hline 1 & & $1.0 \mathrm{E}-6$ & $8.8 \mathrm{E}-6$ & $3.7 \mathrm{E}-7$ & 7.1 & $-{ }^{a}$ & - & - & $2.0 \mathrm{E}-8$ \\
\hline 2 & Cement & $3.5 \mathrm{E}-6$ & $6.7 \mathrm{E}-6$ & $7.0 \mathrm{E}-7$ & $2.0 \mathrm{E}-5$ & $9.0 \mathrm{E}-9$ & - & - & $1.0 \mathrm{E}-9$ \\
\hline 3 & VES & $5.9 \mathrm{E}-5$ & $1.0 \mathrm{E}-5$ & 9.5E-6 & $1.4 \mathrm{E}-6$ & - & - & - & $1.5 \mathrm{E}-8$ \\
\hline 4 & VES & $1.1 \mathrm{E}-5$ & $1.5 \mathrm{E}-6$ & $1.5 \mathrm{E}-6$ & $4.7 \mathrm{E}-6$ & - & - & - & $3.0 \mathrm{E}-9$ \\
\hline 5 & Cement & $2.0 \mathrm{E}-6$ & $7.4 \mathrm{E}-6$ & $1.7 \mathrm{E}-4$ & $1.2 \mathrm{E}-3$ & $3.8 \mathrm{E}-7$ & 4.0E-9 & - & $1.8 \mathrm{E}-5$ \\
\hline
\end{tabular}

a. Cumulative fractional release is essentially equal to zero.

Table II. Cumulative fractional releases from lysimeter field testing compared to those from bench leach testing $(5,8)$.

\begin{tabular}{|c|c|c|c|c|c|c|}
\hline \multirow[b]{2}{*}{ Test type } & \multirow[b]{2}{*}{$\begin{array}{l}\text { Prefilter } \\
\text { number }\end{array}$} & \multirow[b]{2}{*}{$\begin{array}{c}\text { Solidification } \\
\text { agent }\end{array}$} & \multirow[b]{2}{*}{ Radionuclide } & \multicolumn{3}{|c|}{ Cumulative fractional release } \\
\hline & & & & $\begin{array}{c}\text { Demineralized } \\
\text { water }\end{array}$ & Soil & Sand \\
\hline Bench & 7 & VES $^{a}$ & Strontium -90 & $4.5 \mathrm{E}-2$ & - & - \\
\hline Bench & 7 & Cement $^{a}$ & Strontium-90 & $7.8 \mathrm{E}-2$ & - & - \\
\hline Bench & 7 & $\mathrm{VES}^{\mathrm{a}}$ & Cesium-137 & 4.0E-2 & 一 & - \\
\hline Bench & 7 & Cement $^{a}$ & Cesium-137 & $9.0 \mathrm{E}-2$ & - & - \\
\hline Bench & 7 & VES & Cesium-137 & 2.1E-3 & - & - \\
\hline Bench & 7 & Cement & Cesium-137 & 4.8E-2 & - & - \\
\hline Bench & 24 & VES & Cesium-137 & 3.0E-4 & - & - \\
\hline Bench & 24 & Cement & Cesium-137 & 2.3E-2 & 一 & - \\
\hline Field, ANL-E & 7 & VES & Strontium-90 & - & $9.5 \mathrm{E}-6$ & - \\
\hline Field, ANL-E & 7 & Cement & Strontium-90 & - & $3.7 \mathrm{E}-7$ & $1.7 \mathrm{E}-4$ \\
\hline Field, ANLE & 24 & VES & Strontium-90 & - & $1.5 \mathrm{E}-6$ & - \\
\hline Field, ANL-E & 24 & Cement & Strontium-90 & - & $7.0 \mathrm{E}-7$ & - \\
\hline Field, ORNL & 7 & VES & Strontium-90 & - & $1.4 \mathrm{E}-6$ & - \\
\hline Field, ORNL & 7 & Cement & Strontium-90 & - & 7.1E-5 & - \\
\hline Field, ORNL & 24 & VES & Strontium-90 & - & 4.7E-6 & - \\
\hline Field, ORNL & 24 & Cement & Strontium-90 & - & $2.0 \mathrm{E}-5$ & $1.2 \mathrm{E}-3$ \\
\hline Field, ORNL & 7 & VES & Cesium-137 & - & $1.5 \mathrm{E}-8$ & - \\
\hline Field, ORNL & 7 & Cement & Cesium-137 & - & $2.0 \mathrm{E}-8$ & - \\
\hline Field, ORNL & 24 & VES & Cesium-137 & - & $3.0 \mathrm{E}-9$ & - \\
\hline Field, ORNL & 24 & Cement & Cesium-137 & - & $1.0 \mathrm{E}-9$ & $1.8 \mathrm{E}-5$ \\
\hline
\end{tabular}




\section{Upward Migration of Radionuclides at ORNL}

During previous samplings, the presence of both cesium- 137 and strontium- 90 were discovered at the surface of lysimeter ORNL-5, which is the sand-filled control. Radionuclide activity was first detected during a routine gamma survey of the lysimeter's surface in 1991. At that time, more activity was found near the center than at the edges. Core samples were obtained from the center of the lysimeter at depths from 0 to $2.5 \mathrm{~cm}$ and from 2.5 to $5 \mathrm{~cm}$ for analysis of cesium and strontium-90. Scientists detected $1,760 \mathrm{pCi}$ cesium-137, $10 \mathrm{pCi}$ cesium-134, and $0.5 \mathrm{pCi}$ strontium-90 per gram of sand in the 0 to $2.5-\mathrm{cm}$ core, and $306 \mathrm{pCi}$ cesium-137, $3 \mathrm{pCi}$ cesium-134, and $0.1 \mathrm{pCi}$ strontium- 90 in the 2.5 to $5-\mathrm{cm}$ core material. These data showed that more radionuclides were at the surface, suggesting some type of an active deposition mechanism. There remained a question, however, concerning the source of the radionuclides. In August of 1992, samples were again taken from the lysimeter and analyzed for cesium-137 and cesium-134. The results were similar to the previous sampling, with $1,533 \mathrm{pCi}$ cesium-137 and $6 \mathrm{pCi}$ cesium-134 being found per gram in the surface, and $574 \mathrm{pCi}$ cesium-137 and $2.4 \mathrm{pCi}$ cesium-134 per gram in the 2.5 to $5-\mathrm{cm}$ sample. A comparison was made between the ratio of cesium-137 and cesium-134 in the surface material and the ratio in the buried waste form. It was concluded that the contamination of cesium came from the waste form.

On January 31, 1994, two cores of sand $80 \mathrm{~cm}$ long were collected from lysimeter 5 . One core was taken from the side of the lysimeter near the wall and has not yet been analyzed. The other core was removed from the center of the lysimeter directly above the buried waste form (located approximately $100 \mathrm{~cm}$ below the sand surface). This sand core was sectioned into $5-\mathrm{cm}$ segments. Radiocesium and strontium activity were measured for each segment.

The analyses show that cesium- 137 is present throughout the length of the core (Table III). There are three peaks seen in the cesium content: one at 30 to $35 \mathrm{~cm}$, a large peak at 45 to $50 \mathrm{~cm}$, and a smaller peak at 70 to $75 \mathrm{~cm}$. These peaks may be indicative of some sort of periodic movement of the cesium, but further laboratory study is necessary before the cause of this movement can be determined.

During the sectioning of the core, it was noticed that there was a fine plant root present throughout the depth of the core. The root material was extracted from each segment and counted (Table III). Cesium-137 activity is associated with the root, and the peaks in the root data occur at the same depths as do the peaks in the sand activity. It can be seen that there are higher concentrations of cesium-137 associated with the root than with the sand. Sand from the deepest three segments was analyzed: each whole segment was analyzed, and two subsamples of each segment were analyzed. Segment 2 (Table III) has a fairly wide range of activities between the whole segment and the two subsamples, suggesting that the activity in the sand is not evenly distributed. This could be a result of the root being involved in the transport process.

Strontium-90 analysis results show that there is significant strontium throughout the entire depth of the core (Table III). Peaks occur in the distribution at the same depths as for cesium in both the sand and roots. This suggests that the same mechanism may be involved for transporting strontium upward as cesium. Strontium and cesium behave very differently chemically, suggesting that the process of migration is more physical than chemical, such as evapotranspiration enhanced 
Table III. Cesium and strontium analyses for sand segments and root fragments from ORNL lysimeter 5 collected on January 31, 1994.

\begin{tabular}{|c|c|c|c|c|c|}
\hline \multirow[b]{2}{*}{ Segment \# } & \multirow[b]{2}{*}{$\begin{array}{l}\text { Depth } \\
(\mathrm{cm})\end{array}$} & \multicolumn{3}{|c|}{ Sand } & \multirow{2}{*}{$\begin{array}{c}\text { Plant root } \\
\begin{array}{c}\text { Cesium-137 } \\
(\mathrm{pCi} / \mathrm{g})\end{array}\end{array}$} \\
\hline & & \begin{tabular}{|c} 
Sample weight \\
(g)
\end{tabular} & $\begin{array}{c}\text { Cesium-137 } \\
(\mathrm{pCi} / \mathrm{g})\end{array}$ & $\begin{array}{c}\text { Strontium-90 } \\
(\mathrm{pCi} / \mathrm{g})\end{array}$ & \\
\hline 1 & $80-75$ & 100.68 & 598.1 & 1.5 & 18,900 \\
\hline 1 & $80-75$ & 17.08 & 704.5 & - & - \\
\hline 1 & $80-75$ & 17.16 & 660.8 & - & - \\
\hline 2 & $75-70$ & 118.92 & $1,303.4$ & 3.5 & 20,660 \\
\hline 2 & $75-70$ & 17.48 & 2,241 & - & - \\
\hline 2 & $75-70$ & 20.37 & 1,550 & - & - \\
\hline 3 & $70-65$ & 121.53 & 356.7 & 2.0 & 20,480 \\
\hline 3 & $70-65$ & 19 & 400.7 & - & - \\
\hline 3 & $70-65$ & 14.85 & 376 & - & - \\
\hline 4 & $65-60$ & 115.25 & 490.2 & 2.1 & 22,540 \\
\hline 5 & $60-55$ & 117.07 & 403.3 & 2.7 & 27,520 \\
\hline 6 & $55-50$ & 125.28 & 1,594 & 7.6 & 27,360 \\
\hline 7 & $50-45$ & 129.06 & $37,283.1$ & 14.1 & 81,970 \\
\hline 7 & $50-45$ & 17.79 & 14,160 & - & - \\
\hline 8 & $45-40$ & 121.14 & 551.2 & 1.5 & 13,620 \\
\hline 9 & $40-35$ & 116.32 & 866.6 & 3.5 & 10,150 \\
\hline 10 & $35-30$ & 122.86 & $5,484.2$ & 7.6 & 21,580 \\
\hline 10 & $35-30$ & 17.5 & 5,172 & - & - \\
\hline 11 & $30-25$ & 117.94 & 2032.4 & 16.0 & 5,990 \\
\hline 12 & $25-20$ & 125.78 & 1,513 & 0.5 & 3,850 \\
\hline 13 & $20-15$ & 94.99 & 711.7 & 0.2 & 5,940 \\
\hline 14 & $15-8.5$ & 150.30 & 715.2 & 0.6 & 8,570 \\
\hline
\end{tabular}

by the presence of the root. The fact that the sand has a very low cation-exchange capacity is probably the reason that the physical aspect of migration is so evident. Further analysis of soil cores is planned. ORNL scientists performed gamma-radiation surveys of gravimetric soil cores collected annually, and determined that soil-filled lysimeters are not experiencing upward migration of radionuclides.

\section{SOURCE TERM MODELING OF LYSIMETER RELEASES}

The Disposal Unit Source Term (DUST) (9) code was used to model the release of the radionuclides cesium-137 and strontium-90 from the lysimeter waste forms. DUST is a one-dimensional code that accounts for container performance and waste form leaching (including diffusion-controlled release). Transport can be modeled through finite differences or by a multicell mixing cascade approach. The finite difference method was used in the simulations reported in this paper because it is more general than the mixing cell approach and permits modeling of 
dispersive transport. Use of these data in the DUST code was examined in detail in a paper presented at WM'93 (10).

The releases of cesium-137 and strontium-90 from Portland type I-II cement located in the inert, sand-filled lysimeters 5 at ORNL and ANL-E were chosen because releases from other lysimeters were substantially lower; therefore, the data were not yet sufficient to model. At ANL, lysimeter 5 contained resin waste from PF-7 solidified in Portland type I-II cement; at ORNL, lysimeter 5 contained resin waste from PF-24, which was also solidified in cement (Table I). Diffusion coefficient values measured in laboratory testing of these waste forms were $9.6 \mathrm{E}-10 \mathrm{~cm}^{2} / \mathrm{s}$ for strontium-90 in Portland cement (8) and $5 \mathrm{E}-11 \mathrm{~cm}^{2} / \mathrm{s}$ for cesium-137 in Portland cement (5). The Darcy velocities ranged from $2.59 \mathrm{E}-6 \mathrm{~cm} / \mathrm{s}$ at ANL-E to $3.6 \mathrm{E}-6 \mathrm{~cm} / \mathrm{s}$ at ORNL (7). The soil bulk density values were $1.55 \mathrm{~g} / \mathrm{cm}^{3}$ at ANL-E and $1.60 \mathrm{~g} / \mathrm{cm}^{3}$ at ORNL (6). Moisture content values were calculated using the effective soil porosity and the fraction of saturation values found in Reference (7). The dispersivity and retardation $\left(\mathrm{K}_{\mathrm{d}}\right)$ coefficients have not been measured for strontium-90 or cesium-137 in this sand; therefore, they were estimated based on data in References (11) and (12) and by fitting the model predictions to the data. The cumulative activity collected in the lysimeter leachate water over the first 9 years of operation of the experiment, which was used to make comparisons to the DUST code predictions, represented cumulative fractional releases of about 0.0012 and 0.00017 of the strontium-90 in lysimeter 5 at ORNL and ANL-E, respectively (Table I).

As shown in Figure 4, the actual data for strontium-90 from ORNL lysimeter 5 are compared with the DUST code predictions of releases in case 1 using zero dispersive flux $B C, K_{d}=24$, and dispersivity $=8.5$. Also shown are predicted releases of case 2 using zero concentration flux $\mathrm{BC}$, $K_{d}=10$, and dispersivity $=0.6$. The measured waste form diffusion coefficient of $9.6 \mathrm{E}-10 \mathrm{~cm}^{2} / \mathrm{s}$ was used. The predicted releases show a very good fit to the actual data after initial stabilization of the test data. Case 2 releases less activity over 4 years than case 1 ; however, over 20 years, case 2 will have released $33 \%$ of the total strontium-90 inventory, whereas case 1 will have released $3.3 \%$ of the total strontium-90 inventory. The lack of measured dispersivity and retardation coefficient necessitates obtaining cumulative release data over a longer term.

\section{CONCLUSIONS}

The radionuclide that has appeared with most regularity at both sites is strontium-90, although cesium-137 is observed regularly in the leachate of all ORNL lysimeters. A comparison of total strontium-90 found in leachate of the control lysimeters shows that environmental effects have resulted in a much higher release at ORNL. The data indicate that Portland cement and VES waste forms have comparable releases of strontium- 90 .

Cesium-137, cesium-134, and strontium-90 are present throughout the upper $80 \mathrm{~cm}$ of the inert sand in ORNL lysimeter 5 directly above the waste form. The ratio of cesium-137/ cesium-134 indicates that the radionuclides are from the buried waste form and not from an outside source and were transported vertically upward by some physical mechanism enhanced by the presence of a plant root. 


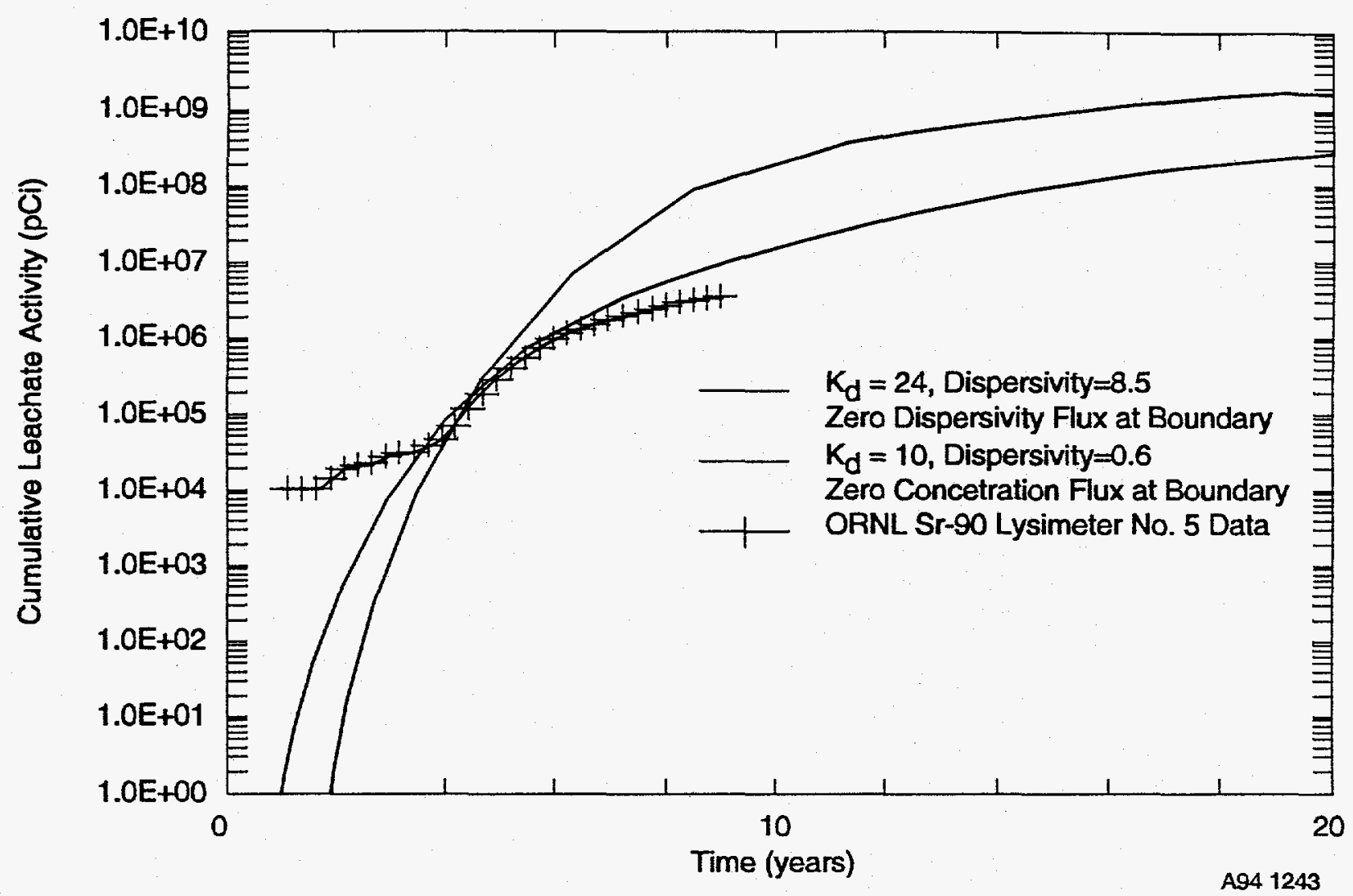

Figure 3. Cumulative release of strontium- 90 at ORNL lysimeter 5 over 9 years, compared with DUST predictions using two sets of estimated $\mathrm{K}_{\mathrm{d}}$ and dispersivity values over 20 years.

DUST-predicted cumulative release of strontium-90 from ORNL lysimeter 5, which was plotted over the first 9 years of data collection, show a reasonable fit to the field data for $\mathrm{K}_{\mathrm{d}}=24$. The accuracy of the DUST modeling study was limited, however, by the lack of measured soil dispersivity and retardation coefficients. Further testing will provide larger cumulative releases to better model the release patterns from the lysimeters.

Data provided by these lysimeter experiments have been shown to be useful in computing many parameters used as input to performance assessment codes. The utility of this reliable source of data will be demonstrated through continued operation of the lysimeters with application of the results to source term models such as DUST. NRC planning recommends that this experiment be augmented by experiments containing solidified decontamination wastes and activated metals from commercial nuclear power stations.

\section{ACKNOWLEDGMENTS}

This work was supported by the U.S. Nuclear Regulatory Commission, Office of Nuclear Regulatory Research, under U.S. Department of Energy Idaho Operations Office Contract DE-AC07-94ID13223. 


\section{REFERENCES}

1. CODE OF FEDERAL REGULATIONS, 10 CFR 61, "Licensing Requirements for Land Disposal of Radioactive Wastes," Office of the Federal Register (1982).

2. U.S. NUCLEAR REGULATORY COMMISSION, "Technical Position on Waste Form," Low-Level Waste Management Branch, Washington, DC (1983).

3. U.S. NUCLEAR REGULATORY COMMISSION, "Technical Position on Waste Form," Revision 1, Low-Level Waste Management Branch, Washington, DC (1991).

4. R. M. NEILSON and J. W. MCCONNELL, JR., "Solidification of EPICOR-II Resin Waste Forms," GEND-INF-055 (1984).

5. R. M. NEILSON, JR. and J. W. MCCONNELL, JR., "EPICOR-II Resin Waste Form Testing," NUREG/CR-4637, EGG-2457 (1986).

6. R. D. ROGERS, J. W. MCCONNELL, JR., E. C. DAVIS, and M. W. FINDLEY, "Field Testing of Waste Forms Containing EPICOR-II Ion Exchange Resins Using Lysimeter," NUREG/CR-4498 (1986).

7. J. W. MCCONNELL, JR., R. D. ROGERS, J. D. JASTROW, D. S. WICKLIFF, and T. M. SULLIVAN, "Annual Report of the Lysimeter Field Investigations: Low-Level Waste Data Base Development Program for Fiscal Year 1993," NUREG/CR-5229, Vol. 6 (1994).

8. R. D. ROGERS, J. W. MCCONNELL, JR., E. C. DAVIS, and J. D. JASTROW, "Annual Report of the TMI-2 EPICOR-II Resin/Liner Investigation: Low-Level Waste Data Base Development Program for Fiscal Year 1988," NUREG/CR-5229, Vol. 1 (1988).

9. T. M. SULLIVAN, "Disposal Unit Source Term (DUST) Data Input Guide," NUREG/CR-6041, BNL-NUREG-52295, 1993.

10. T. M. SULLIVAN, J. W. McCONNELL, JR., R. D. ROGERS, and I. T. FITZGERALD, "Modeling of Field Lysimeter Release Data Using the Computer Code DUST," Waste Management '93 Proceedings of the Symposia on Waste Management, Tucson, AZ, February 28 to March 4, 1993, Vol. 1, pp. 781-5.

11. D. ISHERWOOD, "Geoscience Data Base Handbook for Modeling a Nuclear Waste Repository," NUREG/CR-0912, Vol. 1 (1981).

12. R. A. FREEZE AND J. A. CHERRY, "Groundwater," Chapter 9, pp. 430-432, Prentice-Hall, Inc., Englewood Cliffs, NJ (1979). 